\title{
Mutagenic Effectiveness and Efficiency of Gamma Rays in Indian mustard (Brassica juncea L. Czern and Coss)
}

\author{
T. Julia, Th. Renuka*, H. Nanita and S. Jambhulkar \\ Department of Genetics and Plant Breeding, College of Agriculture, Central Agricultural \\ University, Imphal-795004, India \\ *Corresponding author
}

\section{A B S T R A C T}

\section{Keywords \\ Mutagens, Effectiveness, Efficiency, Gamma rays, Chlorophyll mutants, \\ $\mathrm{LD}_{50}$ \\ Article Info \\ Accepted: \\ 26 February 2018 \\ Available Online: \\ 10 March 2018}

Mutagenic effectiveness and efficiency of gamma rays were studied in three genotypes of Indian mustard (two local cultivars and one improved variety). From the present study, it was suggested that the $\mathrm{LD}_{50}$ ranging from $1000 \mathrm{~Gy}$ (pollen sterility) to $1200 \mathrm{~Gy}$ or above (survival reduction) may be used for gamma ray treatment in Indian mustard. Five types of chlorophyll mutants were observed in the order of Albina> Chlorina=Viridis> Xantha=Alboviridis. The highest mutation frequency was recorded from $1000 \mathrm{~Gy}$ gamma ray treatment which was followed by 1200 Gy. Mutagenic effectiveness was found to be highest at $1000 \mathrm{~Gy}$ gamma ray treatment. The mutagenic efficiency, in terms of lethality, was found to be the highest at $800 \mathrm{~Gy}$. However, mutagenic efficiency for both injury and sterility was found to be highest at $1000 \mathrm{~Gy}$.

\section{Introduction}

Among the oilseeds, rapeseed-mustard group is the second major group cultivated in India contributing nearly $1 / 3^{\text {rd }}$ of the edible oil pool of the country (Pratap et al., 2014). Being a Rabi crop that grows well under conserved moisture, it has greater potential to increase the availability of edible oil from the domestic production. Rapeseed and mustard oil is consumed in several ways as cooking, frying and preparation of pickles and the meal as cattle feed, the green tender plant is also used as vegetable. The average yield of rapeseedmustard in India is $1089 \mathrm{~kg} / \mathrm{ha}$ in the year 2016 which is very low; roughly was about two-third of the world's average of 1695 $\mathrm{kg} / \mathrm{ha}$. The demand for rapeseed and mustard oil outstrips the production and as a result, India is importing on an average 46.8 lakh tonnes of edible oil to meet its requirement during the last five-six years at a cost of around 10,000 crores annually. Population pressure coupled with better standards of living, low oilseed production due to aberrant weather for several years and liberalization of import-export policy are the major causes behind such an import scenario (Kumar, 2012).

Thus, there is an urgent need to enhance the production and productivity of this crop by all means and ways. Genetic variation plays a critical role in developing well-adapted 
improved cultivars. A good variability should be present in the primary gene pool (Kumar et al., 2015). With the available literature, in India, there is limited genetic variability in primary gene pool of Brassica juncea, so, the various tools to generate new genetic variability shall be employed. Mutation breeding might be the effective alternate to augment genetic variation, particularly for traits having low level of genetic variation (Szarejko and Forster, 2007). Induced mutations have been used mainly to generate variation that could rarely be found in germplasm collections in a comparatively short time. Only through a careful screening and selection programme, the magnitude of genetic variability induced by mutagens could be exploited for obtaining the desirable lines.

Among the different mutagenic agents, irradiation has been successfully used for induced mutation breeding in various crops and ornamental plants and has proven a skillful means of encouraging the expression of recessive genes and producing new genetic variations (Song and Kang, 2003). Most of the mutant varieties (89\%) have been developed worldwide using physical mutagens (X-rays, gamma rays, thermal and fast neutrons), with gamma rays alone accounting for the development of $60 \%$ mutant varieties (Kharkwal et al., 2004).

Gamma-rays have been extensively used to induce mutations in crop plants as they do not pose a threat for humankind and environment. Gamma rays are the most energetic form of electromagnetic radiation, their energy level is from ten to several hundred kilo electron volts and they are considered as the most penetrating compared to other radiations (Kovacs and Keresztes, 2002). The usefulness of a mutagen in mutation breeding depends on its mutagenic effectiveness (mutation per unit dose of mutagens) and efficiency (mutation in relation to undesirable changes like sterility, lethality, injury, etc.). The selection of effective and efficient mutagen is very essential to recover a high frequency and spectrum of desirable mutations (Mahabatra, 1983; Solanki and Sharma, 1994). The present investigation was undertaken to study the frequency and spectrum of macro mutations along with the mutagenic effectiveness and efficiency of different doses of gamma rays in Brassica juncea.

\section{Materials and Methods}

The present study consisted of three genotypes of Indian mustard viz. CAULC-1 (Potsangbam yella), CAULC-2 (Kakching yella) and PM-25 (Pusa mustard-25, developed by IARI, New Delhi), of which CAULC-1 and CAULC-2 are local cultivars. Fully matured, well dried, disease and insect free seeds with uniform shape, size and colour, as far as practicable, were chosen for gamma irradiation. For gamma ray treatment, the selected seeds for each genotype were divided into six lots which contain 10,000-15,000 seeds per lot in polythene bags. Out of the six lots, one lot of seeds in polythene bags for all the genotype was kept as control ( 0 dose/ $\left.\mathrm{D}_{0}\right)$. The remaining five lots for all the three genotypes were then irradiated separately at $800 \mathrm{~Gy}\left(\mathrm{D}_{1}\right)$, 900Gy $\left(\mathrm{D}_{2}\right), 1000$ Gy $\left(\mathrm{D}_{3}\right), 1100 \mathrm{~Gy}\left(\mathrm{D}_{4}\right)$ and 1200 Gy $\left(D_{5}\right)$ doses of gamma rays. Gamma irradiation was done at " $\mathrm{Co}_{60}$ Gamma chamber 5000” BARC, Trombay, Mumbai, 400085, India with dose rate $3.340 \mathrm{KGy} / \mathrm{hr}$. Altogether there were 18 treatments including the control.

To determine the effect of gamma rays on germination of three genotypes, 100 seeds of each treatment and control were allowed to germinate in petridishes with moist paper. The whole set was replicated three times. The germination percentage ( $\%$ mortality) was counted after 10 days. The $\mathrm{M}_{1}$ generation was raised in Randomized Block Design. All the recommended package of practices was 
followed as and when necessary to raise a good crop of Indian mustard during the period of investigation.

The biological damage (injury, lethality and sterility) was computed as the percentage reduction in seedling height, survival and pollen fertility respectively. At maturity, seeds of $\mathrm{M}_{1}$ plants from each terminal and primary raceme of each treatment were harvested and seeds were bulked dose-wise to raise $\mathbf{M}_{2}$ generation in the next season.

The $\mathrm{M}_{2}$ generation was laid out in Randomized Block Design (RBD) with three replications and wider spacing. The respective control and treatment progenies were screened several times for morphological mutations throughout the crop season. Chlorophyll mutants (Albina, Chlorina, Xantha, Viridis, Alboviridis) were scored in $\mathrm{M}_{2}$ generation according to the classification of Gustafsson (1940) and Blixit (1961). Mutation frequency was calculated as percentage of mutated $\mathbf{M}_{2}$ progenies for both chlorophyll and morphological mutations in each treatment.

Mutation frequency

$=$

No. of mutated progenies

No. of 2 sesdlings analysed for a particlar dose

Mutagenic effectiveness and efficiency were calculated on the basis of formula suggested by Konzak et al., (1965).

$$
\text { Mutagenic effectiveness }=\frac{\text { Mf }}{G_{y}} \times 100
$$

\section{Mutagenic efficiency}

The mutagenic efficiency expressed in terms of injury, lethality and sterility is given as follows:

Injury $=\frac{\text { Mf }}{\mathrm{I}} \times 100$
Lethality $=\frac{\text { Mf }}{\mathrm{L}} \times 100$

Sterility $=\frac{\text { Mf }}{\mathrm{s}} \times 100$

Where,

$\mathrm{Mf}=$ Mutation frequency on $\mathrm{M}_{2}$ seedling basis

Gy $=$ Radiation dose in Gray

$\mathrm{I}=$ Percentage injury i.e. percentage seedling height reduction

$\mathrm{L}=$ Percentage lethality or percentage survival reduction

$S=$ Percentage reduction in pollen fertility or percentage sterility

$\mathbf{L D}_{50}$

Estimation of $\mathrm{LD}_{50}$ value in present investigation was done for percentage reduction in seed germination, seedling survival and pollen fertility in $\mathrm{M}_{1}$ generation using Probit analysis as suggested by Sharma (1988).

\section{Results and Discussion}

\section{$\mathbf{L D}_{50}$}

$\mathrm{LD}_{50}$ i.e. the dose in which half of the individuals among the treated population dies, is a parameter to decide the effective dose for a mutagen treatment in any crop species. The impact and the tolerance level of the biological material to a mutagen are manifested in $\mathbf{M}_{1}$ generation itself in terms of germination, lethality, injury, etc. (Gaul, 1970).

$\mathrm{LD}_{50}$ dose for seed germination i.e. 4254.80 Gy $(425.48 \mathrm{Kr}$ ) exceeded the gamma ray doses administered in the present study. The 
$\mathrm{LD}_{50}$ dose for survival was estimated at 1218.10 Gy $(121.81 \mathrm{Kr})$. The lowest LD $_{50}$ dose, in the present study, was estimated from the pollen sterility percentage as $1100.20 \mathrm{~Gy}$ $(110.02 \mathrm{Kr})$, and was very near to $\mathrm{LD}_{50}$ dose for Brassica napus L. as reported by Li et al., (1993). The dose much below 1100.20 Gy will definitely increase the availability of $\mathrm{M}_{2}$ generation seeds but the mutation induced will not be satisfying and if the dose is more than 1100.20 Gy, then, enough population may not be available to grow $\mathrm{M}_{2}$ generation. Thus, doses just below 1100.20 Gy or equal to $\mathrm{LD}_{50}$ is suggested to use in further mutation program for inducing good mutations while insuring ample amount of individuals for screening those mutations (Table 1).

\section{Mutation frequency}

The frequency of chlorophyll and viable mutants in $\mathrm{M}_{2}$ generation is mainly used as a dependable measure of genetic effect of mutagens (Nilan et al., 1961). Mutation frequency has been used as the indicator of mutagenic effect. The highest identifiable mutation frequency was recorded from 1000 Gy gamma ray treatment which was followed by 1200 Gy gamma ray treatment (Table 2). Such a reduction in mutation frequency at higher doses of gamma ray might be due to the increased damage in the genetic materials and irreparable during the process of plant growth, leading to the death of cells resulting into lethality.

Among the cultivars/varieties studied, the highest mutation frequency was recorded from PM-25 which was followed by CAULC-1. The present result suggested that the Indian mustard cultivars/varieties responded differentially to gamma ray for the production of mutations.

In the present study, it was observed that the most effective dose of gamma ray was 1000
Gy and the most sensitive genotype to gamma ray was PM-25.

\section{Chlorophyll mutants}

The spectrum of chlorophyll mutations and their relative frequencies are presented in Table 3. The following different kinds of chlorophyll mutations were identified in accordance with the classification of Gustafsson (1940) and Blixit (1961).

\section{Albina \\ Lethal mutation characterized by entirely white leaves of seedlings; seedlings survived for 10-12 days after emergence.}

\section{Chlorina}

The seedlings were yellowish green (pale green) in colour. They survived for reasonably longer period.

\section{Xantha}

Leaves were bright yellow in colour. Seedlings survived for 25-30 days.

\section{Viridis}

These are viable mutants characterized by light green leaves which become normal green colour at later stages.

\section{Alboviridis}

These are viable mutants characterized by green base with white apex leaves. However, this mutant died before maturity in the present study.

The spectrum of chlorophyll mutations was determined as the relative proportion of different types of chlorophyll mutants to the total number of chlorophyll mutations (Fig. 19). 
Table.1 $\mathrm{LD}_{50}$ for different growth parameters of three Indian mustard cultivars/varieties in $\mathrm{M}_{1}$ generation

\begin{tabular}{|c|c|c|c|c|c|}
\hline \multirow{2}{*}{$\begin{array}{c}\text { Sl. } \\
\text { no. }\end{array}$} & Characters & \multicolumn{3}{|c|}{ LD } & Mean LD LD $_{50}$ \\
\cline { 3 - 6 } & & CAULC-1 & CAULC-2 & PM-25 & \\
\hline 1. & Germination \% & $2136.20 \mathrm{~Gy}$ & $2268.20 \mathrm{~Gy}$ & $9139.90 \mathrm{~Gy}$ & $4254.80 \mathrm{~Gy}$ \\
2. & Survival \% & $1181.10 \mathrm{~Gy}$ & $1197.40 \mathrm{~Gy}$ & $1274.40 \mathrm{~Gy}$ & $1218.10 \mathrm{~Gy}$ \\
3. & Pollen fertility \% & $1044.90 \mathrm{~Gy}$ & $1067.40 \mathrm{~Gy}$ & $1374.60 \mathrm{~Gy}$ & $1100.20 \mathrm{~Gy}$ \\
\hline
\end{tabular}

Table.2 Frequency of chlorophyll and viable mutants in $\mathrm{M}_{2}$ generation of three Indian mustard cultivars/varieties

\begin{tabular}{|c|c|c|c|c|c|c|c|c|c|c|c|c|}
\hline \multirow{2}{*}{$\begin{array}{l}\text { Dose } \\
(\mathbf{G y})\end{array}$} & \multicolumn{3}{|c|}{ CAULC-1 } & \multicolumn{3}{|c|}{ CAULC-2 } & \multicolumn{3}{|c|}{ PM-25 } & \multicolumn{3}{|c|}{ Total } \\
\hline & $\begin{array}{c}\text { No. of } \\
\mathrm{M}_{2} \\
\text { seedlings }\end{array}$ & $\begin{array}{l}\text { No. of } \\
\text { mutants }\end{array}$ & $\begin{array}{l}\text { Mutation } \\
\text { frequency }\end{array}$ & $\begin{array}{c}\text { No. of } \\
\mathrm{M}_{2} \\
\text { seedlings }\end{array}$ & $\begin{array}{l}\text { No. of } \\
\text { mutants }\end{array}$ & $\begin{array}{l}\text { Mutation } \\
\text { frequency }\end{array}$ & $\begin{array}{c}\text { No. of } \\
\mathrm{M}_{2} \\
\text { seedlings }\end{array}$ & $\begin{array}{l}\text { No. of } \\
\text { mutants }\end{array}$ & $\begin{array}{l}\text { Mutation } \\
\text { frequency }\end{array}$ & $\begin{array}{c}\text { No. of } \\
\mathrm{M}_{2} \\
\text { seedlings }\end{array}$ & $\begin{array}{l}\text { No. of } \\
\text { mutants }\end{array}$ & Mutation frequency \\
\hline 0 & 1056 & - & - & 975 & - & & 933 & - & - & 2964 & - & - \\
\hline 800 & 1113 & 10 & 0.89 & 1053 & 8 & 0.76 & 867 & 13 & 1.49 & 3033 & 31 & 1.02 \\
\hline 900 & 975 & 13 & 1.33 & 945 & 9 & 0.95 & 918 & 12 & 1.31 & 2838 & 34 & 1.19 \\
\hline 1000 & 957 & 15 & 1.57 & 1104 & 7 & 0.63 & 873 & 19 & 2.18 & 2934 & 41 & 1.39 \\
\hline 1100 & 1020 & 10 & 0.98 & 978 & 6 & 0.61 & 819 & 17 & 2.08 & 2817 & 33 & 1.17 \\
\hline 1200 & 894 & 9 & 1.01 & 996 & 9 & 0.90 & 978 & 17 & 1.74 & 2868 & 35 & 1.22 \\
\hline Total & 6015 & 57 & 5.79 & 6051 & 39 & 3.86 & 5388 & 78 & 8.79 & 17454 & 174 & 6.01 \\
\hline
\end{tabular}

Table.3 Spectrum of chlorophyll mutation in $\mathrm{M}_{2}$ generation of three Indian mustard cultivars/varieties

\begin{tabular}{|c|c|c|c|c|c|c|c|c|c|c|c|c|c|c|c|c|c|c|c|c|}
\hline \multirow{3}{*}{$\begin{array}{l}\text { Dose } \\
(\mathbf{G y})\end{array}$} & \multicolumn{20}{|c|}{ Relative frequencies of chlorophyll mutants } \\
\hline & \multicolumn{4}{|c|}{ Albina } & \multicolumn{4}{|c|}{ Chlorina } & \multicolumn{4}{|c|}{ Xantha } & \multicolumn{4}{|c|}{ Viridis } & \multicolumn{4}{|c|}{ Alboviridis } \\
\hline & $\stackrel{\Omega}{S}$ & $\Omega$ & $\begin{array}{l}\text { 离 } \\
\text { ú }\end{array}$ & $\stackrel{+}{\stackrel{0}{0}}$ & $\stackrel{2}{1}$ & $\stackrel{\Omega}{\Omega}$ & $\frac{0}{3}$ & $\stackrel{+}{\stackrel{0}{0}}$ & $\Omega$ & N & $\begin{array}{l}\frac{7}{3} \\
\text { ì } \\
\text { ú }\end{array}$ & $\begin{array}{l}\overrightarrow{0} \\
\stackrel{\Xi}{ \pm}\end{array}$ & $\stackrel{2}{1}$ & N & 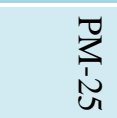 & $\stackrel{-1}{\stackrel{0}{0}}$ & $\stackrel{\Omega}{\Omega}$ & N & $\frac{0}{3}$ & $\stackrel{\overrightarrow{0}}{\stackrel{0}{0}}$ \\
\hline 800 & 33.33 & - & - & 33.33 & 66.66 & - & 100.00 & 166.66 & - & - & - & - & - & - & - & - & - & - & - & - \\
\hline 900 & 50.00 & - & 100.00 & 150.00 & - & - & - & - & 50.00 & - & - & 50.00 & - & - & - & - & - & - & - & - \\
\hline 1000 & - & - & - & - & - & - & - & - & - & - & - & - & - & - & 33.33 & 33.33 & - & - & 66.66 & 66.66 \\
\hline 1100 & - & - & - & - & - & - & - & - & - & - & - & - & - & - & - & - & - & - & - & - \\
\hline 1200 & - & - & - & - & - & - & - & - & - & - & - & - & - & - & 100.00 & 100.00 & - & - & - & - \\
\hline Total & 83.33 & - & 100.00 & - & 66.66 & - & 100.00 & - & 50.00 & - & - & - & - & - & 133.33 & - & - & - & 66.66 & - \\
\hline
\end{tabular}


Table.4 Mutagenic effectiveness of gamma ray doses in $\mathrm{M}_{2}$ generation

\begin{tabular}{|c|c|c|c|c|c|}
\hline \multirow{2}{*}{ Dose (Gy) } & \multicolumn{4}{|c|}{ Mutation frequency } & Effectiveness \\
\hline & CAULC-1 & CAULC-2 & PM-25 & Mean & $\frac{\text { Mx 100 }}{\text { Gray }}$ \\
\hline $\mathbf{8 0 0}$ & 0.89 & 0.76 & 1.49 & 1.05 & 0.131 \\
\hline $\mathbf{9 0 0}$ & 1.33 & 0.95 & 1.31 & 1.19 & 0.132 \\
\hline $\mathbf{1 0 0 0}$ & 1.57 & 0.63 & 2.18 & 1.46 & 0.15 \\
\hline $\mathbf{1 1 0 0}$ & 0.98 & 0.61 & 2.08 & 1.22 & 0.11 \\
\hline $\mathbf{1 2 0 0}$ & 1.01 & 0.90 & 1.74 & 1.21 & 0.10 \\
\hline Mean & 1.16 & 0.77 & 1.76 & - & - \\
\hline
\end{tabular}

Fig.1 Chlorophyll mutant Albina. Fig.2 Chlorophyll mutant Chlorina

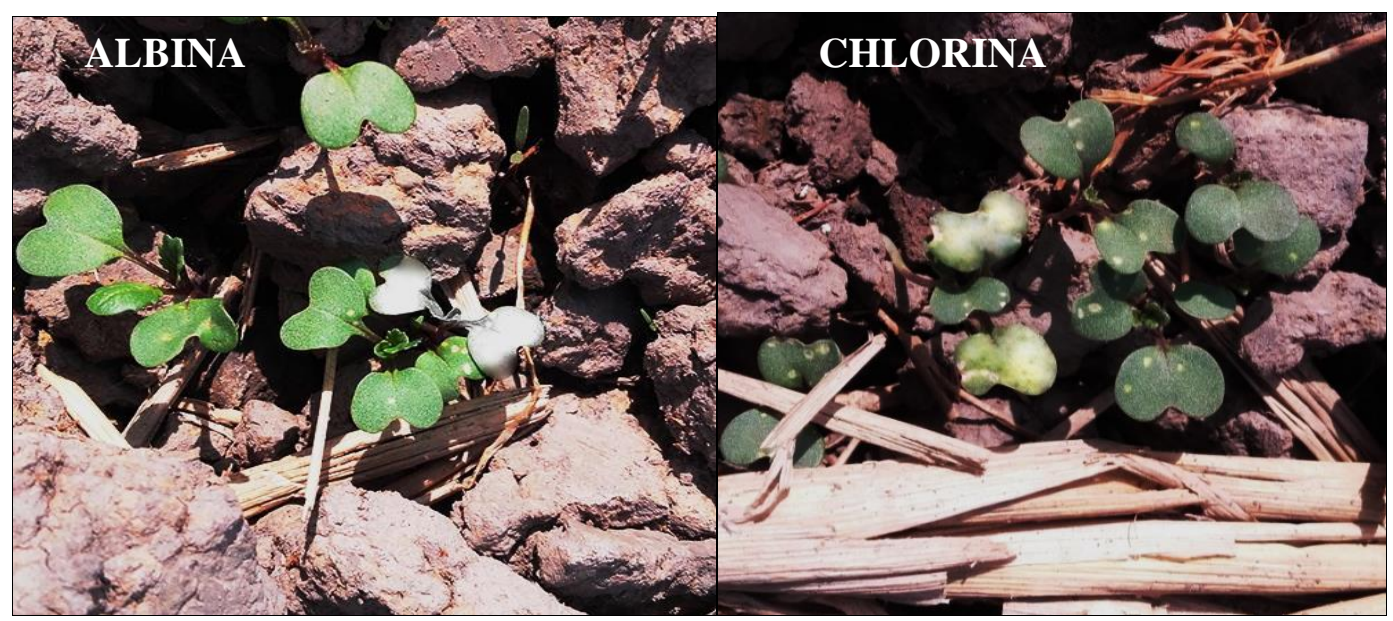

Fig.3 Chlorophyll mutant Xantha. Fig.4 Chlorophyll mutant Viridis

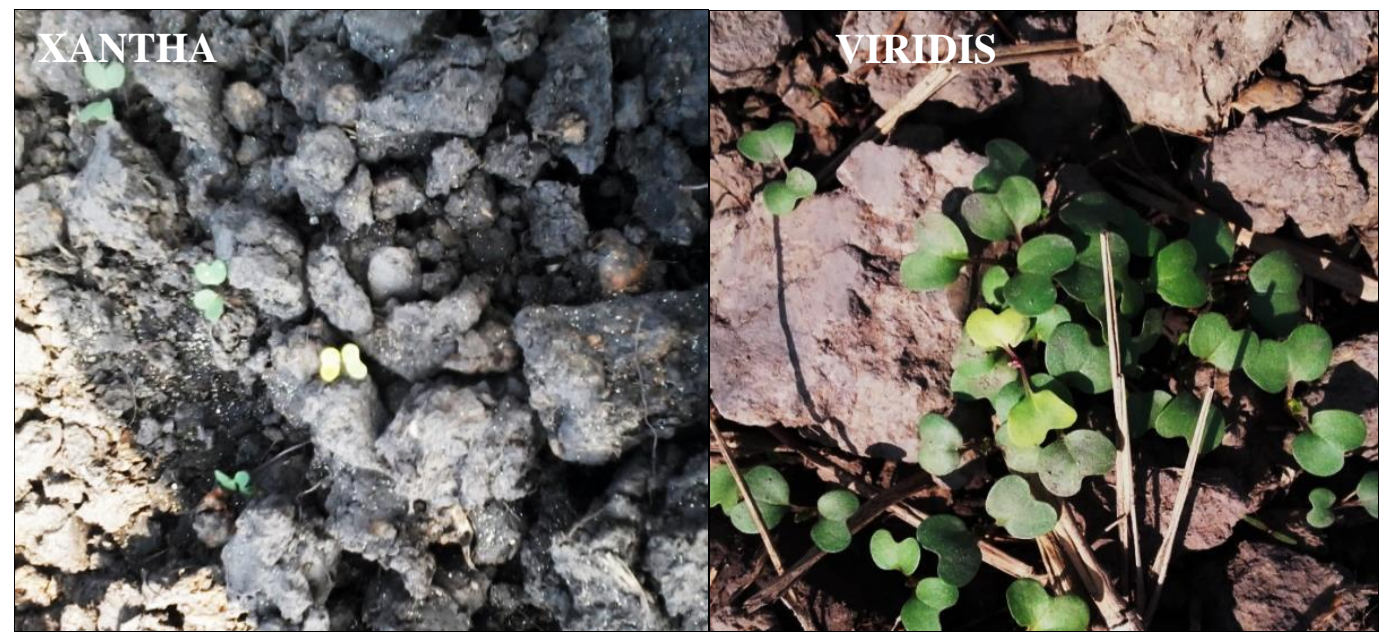


Fig.5 Chlorophyll mutant Alboviridis

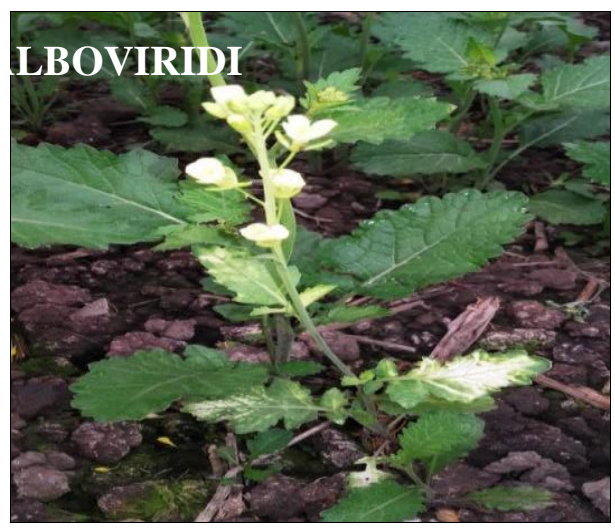

Fig.6 Early mutant

Fig.7 Dwarf mutant

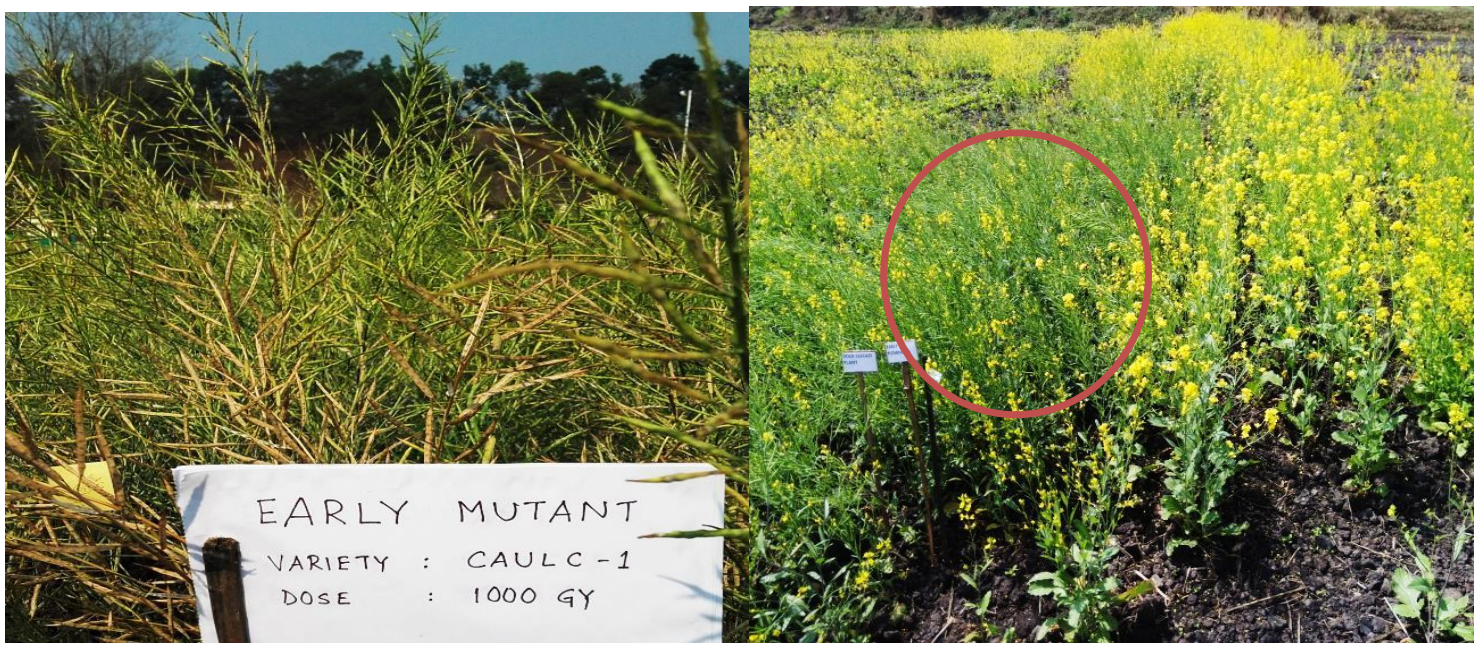

Fig.8 Bold-seeded mutant

Fig.9 Appressed siliqua mutant

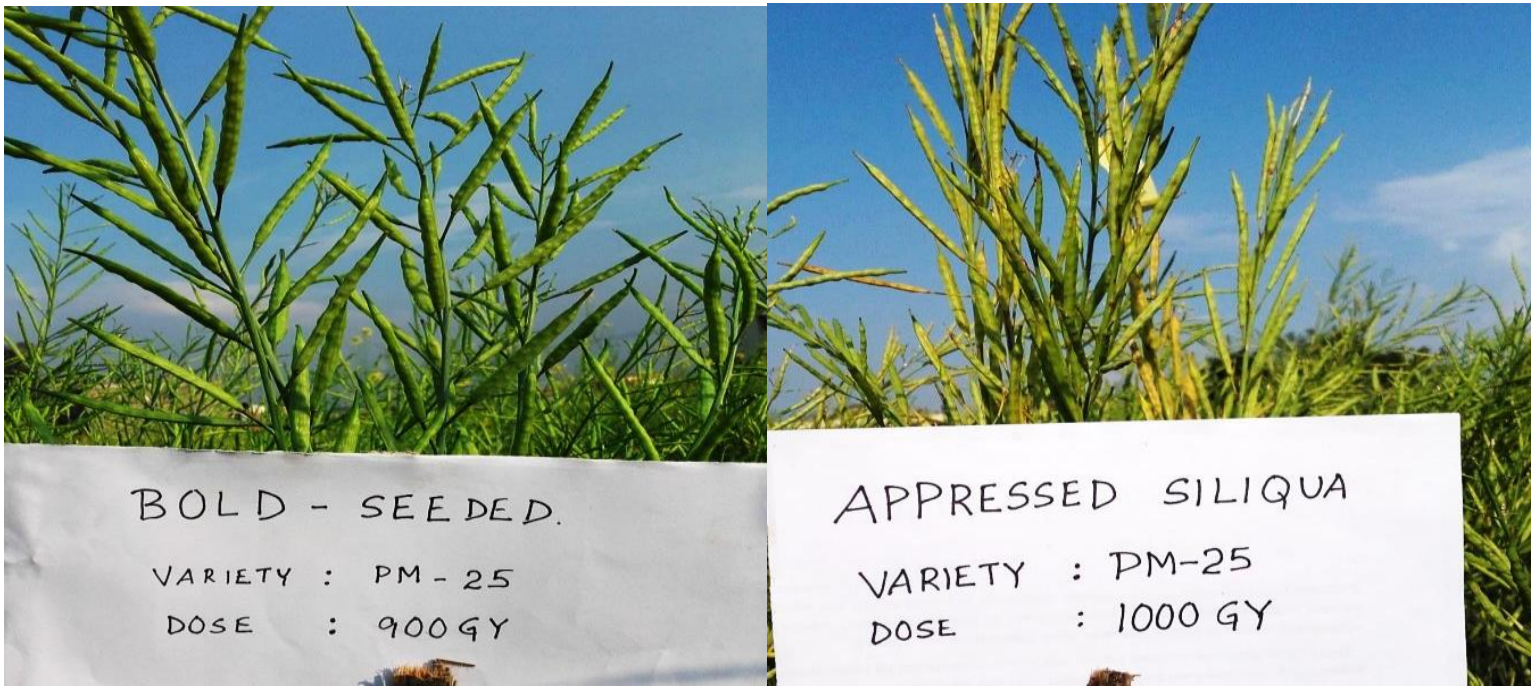


The gamma ray dose 1100 Gy $\left(D_{4}\right)$ did not induce any kind of chlorophyll mutation in all the three cultivars/varieties. The spectrum of chlorophyll mutants was higher in $800 \mathrm{~Gy}$ and 900 Gy treatments. Among the chlorophyll mutants, albina was the most frequent. Albina mutant leaves were white in colour due to absence of all pigments, which leaded to the death of the plants at 10-12 days after germination. Athwal et al., (1970) in chickpea, Karthika and Subbalakshmi (2006) in soybean, Ambavane et al., (2015) in finger millet also reported a higher frequency of albina mutant.

\section{Viable mutants}

Gaul (1964) classified viable mutations as macro and micro mutations, while Swaminathan (1964) grouped them as macro mutations and systematic mutations.

The mutational event may be accompanied by a large change in phenotype. Such changes have the highest significance in plant breeding and have been stressed by several authors. In the present investigation, some morphological (viable) mutants viz. early flowering, dwarf, bold-seeded and appressed siliqua were observed in $\mathbf{M}_{2}$ generation with different doses of gamma rays.

\section{Early mutant}

Early mutants were isolated from the irradiated populations. The mutants matured 7-9 days earlier than the parents in CAULC-1 and CAULC-2, while the mutants matured 12-14 days earlier than the parents in case of PM-25. Induction of earliness has been the most frequent character modified in mutation breeding experiments in many crops including oilseed Brassica (Kharkwal et al., 2004). Development of several early maturing mutants has been reported in oilseed Brassica (Barve et al., 2009; Das et al., 1999).

\section{Dwarf mutant}

Dwarf mutants were isolated from CAULC-1 and CAULC-2. The dwarfness in plant height is associated with earliness in maturity (Olejniczak and Adamska, 1999) which is a highly desirable character in crop plants. Dwarf mutant may be the result of changed gene action due to mutation in the parental line. Reduction in plant height after gamma ray treatment in oilseed Brassica has been reported earlier by Verma and Rai (1980), Shah et al., (1990), Begum and Dasgupta (2014).

\section{Bold-seeded mutant}

Bold-seeded mutants were also isolated from the gamma irradiated populations of CAULC1, CAULC-2 and PM-25. Maximum number of bold-seeded mutants was isolated from 1000 Gy treated populations. These mutants have higher 1000 seeds weight than their parents which indicated an increase in size of seed as a result of induced mutation in Indian mustard. This is in conformity with the findings of Shah et al., (1990) and Javed et al., (2000) who had also reported the boldseeded mutants in oilseed Brassica.

\section{Appressed siliqua}

The appressed siliqua mutants were isolated from the genotype PM-25 only. And, the highest number of such mutants was isolated from 1000 Gy and 1200 Gy irradiated populations. The mutant with appressed siliqua is superior in respect of total number of siliqua/plant. Similar result was obtained earlier by Singh and Sareen (2004) in Brassica juncea.

\section{Mutagenic effectiveness and efficiency}

Effectiveness and efficiency are quite important, as far as use of mutagenesis in crop 
improvement is concerned. Mutagenic effectiveness is a measure of the frequency of mutation induced by a unit dose of mutagen while mutagenic efficiency represents the proportion of mutation in relation to the associated undesirable biological effects (lethality, injury, sterility) induced by mutagen in question (Konzak et al., 1965).

Mutagens induce differential genetic and cytogenetic changes (Fahmy and Fahmy, 1959). Thus, the mutagenic effectiveness and efficiency will also depend upon the nature of induced mutations. In case of sparsely ionizing radiations like gamma rays, the ratio of point mutations to chromosomal aberration is much higher than that in densely ionizing radiations. In order to obtain high effectiveness and efficiency, the mutation effect must greatly surpass other effects in the cell such as chromosomal aberrations, physiological and toxic effects, which reduce cell survival and eliminate mutation. Both mutagenic effectiveness and efficiency generally decreases with increasing dose or concentration. Ravichandran and Jayakumar (2015) reported that low concentrations of mutagens were found to be more effective and efficient as measured on the basis of lethality and injury than treatments with higher concentrations in sesame. The maximum effectiveness and efficiency was observed at $40 \mathrm{KR}$ of gamma rays and $1.5 \mathrm{mM}$ of EMS.

In the present study, the mutagenic effectiveness did not follow a clear cut trend in Indian mustard (Table 4). Mutagenic effectiveness was found to be highest at 1000 Gy followed by 900 Gy and 800 Gy indicating that the mutagenic effectiveness was higher at lower doses. Similar results of higher mutagenic effectiveness at lower mutagen doses were reported by Rahimi and Bahrani (2011) in canola and Ravichandran and Jayakumar (2015) in sesame. Emrani et al., (2012) and Thagana et al., (2013) also reported that $1000 \mathrm{~Gy}$ was the most effective dose in canola and rapeseed respectively. The greater effectiveness at lower doses of mutagens was due to the fact that the biological damage increases with increasing doses (Konzak et al., 1965).

The mutagenic efficiency was found to be the highest at $800 \mathrm{~Gy}$ for lethality, $1000 \mathrm{~Gy}$ for injury and sterility (Table 4). Mutagenic efficiency may differ for different plant tissue or plant part or individuals because of the differential test conditions influencing the expression of the true potential of the agent (Konzak et al., 1965). From the table 4, it is clearly indicated that there was varietal differences in the mutagenic effectiveness and efficiency of gamma ray. Among the varieties under study, PM-25 was found to be the most effective to the gamma ray treatment followed by CAULC-1 and CAULC-2. CAULC-1 was recorded with the highest value of mutagenic efficiency when expressed in terms of lethality and injury. However, in terms of sterility, PM-25 was recorded with the highest value of mutagenic efficiency followed by CAULC-1.

In conclusion, most efficient gamma ray dose was found to be $800 \mathrm{~Gy}$ in Indian mustard whereas 1000 Gy was the most effective dose.

\section{Acknowledgement}

The authors are thankful to the BARC, Trombay, Mumbai for irradiating the experimental materials.

We also wish to extend our deepest gratitude and appreciation to Head of Department of Genetics and Plant Breeding, the Dean, the authorities of College of Agriculture, Central Agricultural University, Imphal and AICRP (Rapeseed-Mustard), DOR, CAU, Imphal for providing all the necessary research facilities throughout the course of investigation. 


\section{References}

Ambavane, A.R., Sawardekar, S.V., Sawantdesai, S.A. and Gokhale, N.B. 2015. Studies on mutagenic effectiveness and efficiency of gamma rays and its effect on quantitative traits in finger millet (Eleusine coracana $\mathrm{L}$. Gaertn). J. Radiat. Res. and Appl. Sci., 8: 120-125.

Athwal, D.S., Bhalla, S.K., Sandhu, S.S. and Brar, H.S. 1970. A fertile dwarf and three other mutants in Cicer. Indian J. Genet. Plant Breed., 30: 261-266.

Barve, Y.Y., Gupta, R.K., Bhadauria, S.S., Thakre, R.P. and Pawar, S.E. (2009). Induced mutations for development of $B$. juncea canola quality varieties suitable for Indian agro-climatic conditions. In: Shu, Q.Y. (ed) Induced Plant Mutations in Genomics Era. Food and Agriculture Organization of the United Nations, Rome, 2009, pp. 373375.

Begum, T. and Dasgupta, T. 2014. Induced genetic variability, heritability and genetic advance in sesame (Sesamum indicum L.). Sabrao J. Breed. and Genet., 46: 21-33.

Blixit, S.1961. Quantitative studies of induced mutations in Peas. V. Chlorophyll mutations. Agric. Hortic. Genet., 19: 402-47.

Das, M.L., Rahman, A. and Malek, M.A. 1999. Two early maturing and high yielding varieties of rapeseed developed through induced mutation technique. Bangladesh J. Bot., 28: 27-33.

Emrani, S.N., Arzani, A., Saeidi, G., Abtahi, M., Banifatemeh, M., Parsa, M.B. and Fotokian, M.H. 2012. Evaluation of induced genetic variability in agronomic traits by Gamma irradiation in canola (Brassica napus). Pak. J. Bot., 44: 1281-1288.
Fahmy, O.G. and Fahmy, M.J. 1959.Differential gene response to mutagens in Drosophila melanogaster. Genetics, 44: 1149-1171.

Gaul, H. 1964. Mutation in plant breeding. Rad. Bot., 4: 155-232.

Gaul, H. 1970. In: Manual on Mutation Breeding, IAEA, Vienna, 119: 85-99.

Gustafsson, A. 1940. The mutation system of the chlorophyll apparatus. Lunds. Univ. Arrsr. N.F. Avd., 30: 1-40.

Javed, M.A., Khatri, A., Khan, I.A., Ahmad, M., Siddiqui, M.A. and Arain, A.G. 2000. Utilization of gamma irradiation for the genetic improvement of oriental mustard (Brassica juncea L. Coss). Pak. J. Bot., 32: 77-83.

Karthika, R. and Subba Lakshmi, B. 2006. Effect of Gamma Rays and EMS on Two Varieties of Soybean. Asian J. Plant Sci., 5: 721-724.

Kharkwal, M.C., Pandey, R.N. and Pawar, S.E. 2004. Mutation breeding for crop improvement. In: Jain, H.K., Kharkwal, M.C. (eds) Plant Breeding - Mendelian to Molecular Approaches. Narosa Publishing House, New Delhi, India, pp. 601-645.

Konzak, C.F., Nilan, R.A., Wanger, J. and Foster, R.J. 1965. Efficient chemical mutagenesis. Radiat. Bot. (Suppl.), 5: 49-70.

Kumar, A. 2012. Production barriers and technological options for sustainable production of rapeseed-mustard in India. J. Oilseed Brassica, 3: 67-77.

Kumar, A., Singh, B.K., Meena, H.S., Singh, V.V., Singh, Y.P. and Singh, D. 2015. Cytomorphological and molecular characterization of $\mathrm{F}_{1}$ hybrids between B. tournefortii and B. rapa. Cytologia, 80: 317-326.

Li Y., Zheng Y. and Cai M. 1993. The improvement of oguCMS and heterosis breeding system in Brassica napus L. 
by mutation breeding. Mutat. Breed. Oilseed Crop., Pp. 37-42.

Mahabatra, B.K. 1983. Studies on comparative spectrum and frequency of induced genetic variability in green gram [Vigna radiate (L.) Wilczek]. Ph.D. Thesis, IARI, New Delhi.

Nilan, R.A. and Konzak, C.F. 1961.Increasing the efficiency of mutation breeding. Mutation and plant breeding. NASNRC, 891: 931-460.

Olejniczak, J. and Adamska, E. 1999. Achievement of mutation breeding of cereal and oilseed crops in Poland. Proc. $3^{\text {rd }}$ Int. Symp. New Genetical Approaches to Crop Improvement-III. Nuclear Institute of Agriculture, TandoJam, Pakistan, pp: 55-63.

Pratap, P., Meena, P.D., Singh, B,K,, Meena, H.S., Meena, S.S., Sharma, P., Majumdar, R. and Singh, D. 2014. Development and evaluation of Alternaria blight tolerant lines in Indian mustard (B. juncea). J. Oilseed Brassica, 5: 141-148.

Rahimi, M.M. and Bahrani, A. 2011. Effect of Gamma Irradiation on Qualitative and Quantitative Characteristics of Canola (Brassica napus L.). Middle-East J. Sci. Res., 8: 519-525.

Ravichandran, V. and Jayakumar, S.2015. Mutagenic effectiveness and efficiency of gamma rays and EMS in sesame (Sesamum indicum L.). Int. J. Res. Bot., 5: 14-19.

Shah, S.A., Ali, I. and Rahman, K. 1990.Induction and selection of superior genetic variables of oilseed rape Brassica napus L. The Nucl., 7: 37-40.
Sharma, J.R.1988. Statistical/Genetical parameters in mutation experiments. In: Statistical and biometrical techniques in plant breeding. New age International (P) Limited, New Delhi, pp. 358-427.

Singh, K.P. and Sareen, P.K. 2004.Induced podding mutants of Indian mustard (Brassica juncea). Crucif. Newsl., 25: 17-18.

Solanki, I.S. and Sharma, B. (1994).Mutagenic effectiveness and efficiency of gamma rays, ethylene imine and N-nitroso-N-ethyl urea in macrosperma lentil (Lens culinaris Medik.). Indian J. Genet., 54(1): 72-76.

Song, H.S. and Kang, S.Y. 2003. Application of Natural Variation and Induced Mutation in Breeding and Functional Genomics: Papers for International Symposium; Current Status and Future of Plant Mutation Breeding. Korean J. Breed. Sci., 35(1): 24-34.

Swaminathan, M.S. 1964. A comparison of mutation induction in diploid and polyploids. The use of induced mutation in plant breeding. Rad. Bot., 5: 619.

Szarejko, I. and Forster B.P. 2007. Doubled haploidy and induced mutation. Euphytica, 158: 359-370.

Thagana, W.M., Ndirangu, C.M., Omolo, E.O., Riungu, T.C. and Kinyua, M.G. 2013. Variability in $M_{2}$ generations and characteristics of advanced mutant lines of rapeseed (Brassica napus L.). J. Agric. Sci., 4: 83-86.

Verma, V.D. and Rai, B. 1980. Mutation in seed coat colour in Indian mustard. Indian J. Agric. Sci., 50: 545-548.

\section{How to cite this article:}

Julia, T., Th. Renuka, H. Nanita and Jambhulkar, S. 2018. Mutagenic Effectiveness and Efficiency of Gamma Rays in Indian Mustard (Brassica juncea L. Czern and Coss). Int.J.Curr.Microbiol.App.Sci. 7(03): 3376-3386. doi: https://doi.org/10.20546/ijcmas.2018.703.390 